\title{
Post UMNO-BN era: Electoral authoritarianism and the change of regime in Malaysia
}

\author{
John Fong Wai Kinn, Benny Teh Cheng Guan \\ School of Social Sciences, Universiti Sains Malaysia \\ Correspondence: Benny Teh Cheng Guan (email: ben@usm.my)
}

Received: 01 October 2020; Accepted: 24 November 2020; Published: 29 November 2020

\begin{abstract}
This paper aims to examine regime change in Malaysia post-GE14. It employs the notion of electoral authoritarianism to understand the importance of elections in legitimizing authoritarian rule. As the UMNO-BN regime employed higher levels of electoral authoritarianism over the years, the people began to put pressure on the regime by demanding for greater accountability, transparency and inclusivity. The outcome of the $14^{\text {th }}$ General Election demonstrated the people's power and was a crucial first step in restoring the democratic system and ending the political dominance of the UMNO-BN. Yet, more recent political developments in the country, amid Covid-19 pandemic, have raised the concerns of how fragile the situation of regime change is. Based on a qualitative method and analyses from in-depth interviews, this paper argues that while regime change was unexpectedly short-lived, the power exercised by the electorates in the GE-14 has not only substantially weakened the once dominant UMNO-BN coalition but also indirectly contributed to new political partnerships and manoeuvrings in an attempt to remain relevant.
\end{abstract}

Keywords: Democracy, electoral authoritarianism, GE-14, Malaysia, regime change, UMNOBN

\section{Introduction}

A change of regime has often proven almost unimaginable in many developing democratic countries. Elections and even protests are important to facilitate better chances of a regime change to happen, but as most cases, incumbent regimes are capable of withstanding pressures like this, prolonging their longevity. More often than not, elections have time and again been manipulated, often painting the misconception that a change of regime or government would lead to chaos and instability. Such manipulation and perception would only occur and feed through nations, which would either be ruled by semi-authoritarian or authoritarian regimes. Malaysia was part of the many nations in Asia that endured a similar long struggle towards a change of resilient regimes. Malaysia had been held by the solid grip of a semi-authoritarian regime for 61 years from the outgoing ruling coalition party, National Front (BN, Barisan Nasional), spearheaded by the dominant party, United Malay National Organisation (UMNO), only until the recent $14^{\text {th }}$ Malaysian General Election in 2018. 
The 2018 General Election defied all opinion surveys and analysis conducted by the government and non-government organisations, as the majority had predicted the odds to be in favour of the ruling party in retaining their power in the government (Moniruzzaman \& Kazi Fahmida Farzana, 2018). The political development of the opposition parties throughout the years since the formation of Barisan Alternatif had grown ever since, uniting and giving the people the liberty to have better alternatives. The people had proven to challenge the ruling coalition throughout the last three elections, through three big pushes; from the denial of the two-third majority in 2008, to the denial of simple majority for a brief period in 2013 and finally, the denial of power in 2018 (Moniruzzaman \& Kazi Fahmida Farzana, 2018). Rather than a violent and drastic overthrow of a semi-authoritarian government, the changes were done in stages through peaceful means.

Given that the change of regime or government in Malaysia has ameliorated the fundamental attributes of democracy such as the people's participation in politics, electoral competitiveness, and some form of liberal and deliberative values in the government, how much of these improved changes would stay permanent after a change of government or even so, would they be able to stand against any future changes in the government? To put it simply, are changes towards the government permanent? In the context of Malaysia, its own unique achievements and challenges are the steppingstone to determine whether or not some attributes of democracy have achieved such compatibility with its people throughout its given time. This paper investigates the state of regime change in Malaysia and how it has impacted the UMNOBN dominance in electoral authoritarianism throughout the decades.

\section{Literature Review}

Some scholars and observers referred to Malaysia's political system as semi-democratic while others referred to it as semi-authoritarian. Either way, both terms have been used interchangeably, with more or less similar definitions. Malaysia's holistic approach towards semi-authoritarianism or semi-democracy can be argued that such an approach was gained during the British colonialism of division and conquest until the Second World War (Case, 1993). Many of the political elites and top leaders right before and after independence were groomed products of the British colonial policy. The British had even favored the ruling and dominant party United Malay National Organization (UMNO) compared to its counterpart such as AMCJA (All Malaya Council of Joint Action) or even the radical Malayan Communist Party (MCP), as the former was more likely to be diplomatic and would not pose significant risk to the British economic control of Malaya, as much of the resources in Malaya would be needed to rebuild Great Britain's postwar economy (Muhamad, 2018). UMNO-BN began shaping and reconstructing the political and electoral systems to remain in control. This eventually led to a one-party dominant system for decades through the practice of electoral authoritarianism (Muhamad, 2018).

Electoral authoritarianism is being defined as states where regimes permit electoral competition but fail to address basic principles of democratic governance, such as ensuring fair and impartial rules for the opposition and tabulating the election results (Kinne \& Marinov, 2012). Under this electoral authoritarian rule, elections are generally inclusive (universal suffrage is present) as well as minimally pluralistic (allowing opposition parties to run), minimally competitive (where opposition is able to win votes while being denied victory) and finally, minimally open (where selected repressive treatment is present and experienced by those who oppose the government) (Schedler, 2006).

Generally, the classification of Malaysian politics as semi-authoritarian or semidemocratic is likely due to the government's inhibition (but not ban) of civil society and 
movement, besides also preventing the transfer of federal-level governance through election that are held regularly. Therefore, the opposition and civil society served more as voices of people's discontent and dissatisfaction than as organizations that could wield autonomous political power. According to Huntington (as cited in Case, 1993) unlike any other distinctive authoritarian regimes which often lack in "feedback mechanisms", the Malaysian government held elections regularly to measure and re-energize the mass support towards the incumbent. With such mechanism, UMNO and its coalition partners were able to retain their unshakable power at the federal level and to assert the high probability of winning the majority support, despite the existence of a degree of discontent. The regime treated elections as tools to distribute patronage, to settle disputes and to reinforce the regime; however, elections are ambivalent in nature as they could also mobilize threats of resistance and factionalism (Schedler, 2006). Lee and Ong (as cited in Case, 1993) specified that in addition to such mechanism, the opposition parties were still able to win votes or seats but were too incapable to win power, and with no other viable alternative other than the incumbent ruling party in charge of the federal power, the opposition was forced to remain as it was. Electoral authoritarianism has always led to the manipulation of elections at some level - political candidates being barred from participating; news media being censored and to a certain extent, being used for the governing regime's propaganda, gerrymandering or the heavy tampering of election results. Such frequent manipulations have triggered outrage, with most of it expressed as political unrest and mass dissent or some form of anti-regime mobilization (Shirah, 2016).

Throughout the 61 years of Barisan Nasional ruling, the prime ministership would be occupied by an UMNO leader. From the 1980s to early 2000s, BN managed to increase its political dominance, strengthen its authoritarian rule, reduce the role of civil societies and the opposition, and improve electoral popularity through gerrymandering (Slater, 2003). The change of leadership in 2003 to Abdullah Badawi had shown signs of gradual improvement in political liberties, election competitiveness, parliamentary representative and democracy; yet, a sign of change of government was still nowhere near to be achieved. Rather than a complete breakdown of democracy, the nation under UMNO leadership settled down with electoral authoritarianism, either halting their democratizing development or reversing any progress made before (Case, 2011). Schedler (2006) showed that electoral systems practiced by such regimes fall into the wide and foggy zone between liberal democracy and closed authoritarianism. As such, regimes that combine democratic and authoritarian features were neither democratic nor authoritarian, giving rise to the concept of 'hybrid regimes'.

The longevity of the UMNO-BN regime throughout 61 years of ruling could also be due to its hybridism of electoral authoritarianism that limits civil rights, but also features multiparty elections that include some fundamentals of democratic procedure. Malaysia was a nation with a sophisticated authoritarian regime as it possessed a majority of indicators and was able to sufficiently mimic some fundamental aspects of democracy, and only suffered retrograding in the later stage of Najib's era (Morgenbesser, 2020). Due to weak policy responsiveness towards the rule of law and the minorities, the government was held to be more accountable through elections by some quarters (Case, 2011). Despite their perfect mechanism that promoted indefinite rule under the notion of electoral authoritarianism and the strength of semi-authoritarian governance, the ruling party of UMNO and its coalition suffered a landslide defeat in the Malaysian $14^{\text {th }}$ general election, which resulted in a change of the federal government for the first time since achieving independence. Lindberg (2007) found that the institution and repetition of elections in non-democratic nations may change the political landscape and its institutions, which indirectly promotes political liberalization. Fundamentally, elections in non-democratic regimes may give the opposition an opportunity to challenge and possibly remove incumbents, despite the unfavorable odds and low success rate. If the regime miscalculates its popularity, elections could become a crippling tool to undercut the regime 
(Ong, 2018). Lindberg (2007) further argued that when such regimes offer the citizens the opportunity to vote, even in a controlled election or is vulnerable to massive fraud, citizens can contemplate their participatory role as voters, putting some form of belief that the regime should be accountable to the people rather than treating the people as mere subjects of the regime. While electoral authoritarianism may favour authoritarian leaders and governments, it also carries significant trade-offs in terms of mobilizing mass resistance to the policies of authoritarian regimes. In short, even an election held in an authoritarian manner could democratize the nation's political system (Shirah, 2016).

Malaysia's regime change is not just a simple change of government wherein a new party assumed governance right after the old ruling party had lost in the polls. A classic visualization of a liberal and democratic state that frequently undergoes such change would be the United Kingdom and the United States. Tony Blair's Labour party and David Cameron's Conservative party; Bush Republicans and Clinton Democrats, each had very few essential differences when it came to values and policies that had been always associated with the wellbeing of the nation such as human rights, foreign policy, international trade, etc. (Loh, 2018). Regime change is distinctively different from systemic change where fundamental institutions and policies undergo comprehensive changes such as formulating new constitution and introducing massive reforms. Malaysia's regime change is categorized between a simple government change and a systemic change where fewer comprehensive changes were seen, and changes that had taken place in an existing stable government (Loh, 2018).

\section{Methods and Study Area}

Qualitative research method is employed in this paper as it investigates strategies that yield data that are not in numerical form. It is thought to be more flexible in application and can be adjusted according to changing and different situations. This research was conducted through a qualitative analysis and armchair study where knowledge mostly came from primary sources such as multiple in-depth interviews and secondary sources respectively. Analysis, review and comparison on those primary and secondary sources were carried out. In-depth interviews were one of the main highlights of qualitative research methods used. One of the key features in this method was the prompting of open-ended questions based on an interview guide, then probing for answers. Its application involved extracting information from main informants and exploring an individual's or organisation's perspectives on a topic. Six interviewees comprised of diverse backgrounds (academic, politicians, civil society movement, activist and political analyst) were interviewed to provide varying perspectives towards the events and the role their organisations played on the changes that took place in Malaysia's political system.

\section{Results and Discussion}

The regime changes in Malaysia underwent a slow and gradual change. Multiple parties had different and divided ideas of change; some had wanted the then Prime Minister Najib out from office or to be charged with corruption while others wanted the Barisan Nasional regime to be removed from power or to address the increasing cost of living (Personal communication, October 2, 2019). Some even wanted an immediate change of policies and laws once there was a new government takeover, such as imposing a two-term limit on the Prime Minister's tenure (Personal communication, November 18, 2019). A change of regime in Malaysia did not happen immediately. It went through multiple general elections, particularly during the GE-12 in 2008. The Pakatan Rakyat (PR) coalition managed to capture 3 states located in the industrial 
belt of Malaysia, which are part of the global economy and major contributors to the Malaysian coffers. These states were viewed as more financially independent and therefore less dependent on the federal government compared to other states such as Sabah and Kelantan, which required a significant amount of federal funds from time to time (Loh, 2009). Despite electoral authoritarianism, the people in wealthier states like Penang and Selangor saw a viable alternative and stability in the PR coalition compared to Barisan Nasional that led to a change in state-level governments in GE-12.

The democratic momentum towards GE-12 and the subsequent elections are possibly due to several contributing factors. Firstly, there was a difference in leadership between Abdullah Badawi and his predecessor, Mahathir Mohamad. While opposition parties and democratic communities were dealt with through mass arrests and the use of force during Mahathir's era, Badawi had resorted to a more judicious arrest and had avoided race baiting at all cost (Loh, 2009). Secondly, the opposition forces had gathered greater strength in numbers and were able to penetrate the civil society throughout the years. Finally, the developmentalism approach employed by $\mathrm{BN}$ had probably reached its threshold in terms of economic development, a level that was no longer considered to be sacred (Loh, 2009). It was becoming less effective as a form of bargaining chip for BN to obtain support from the people. BN's offer in providing a continuous supply of 'bread and butter' was no longer sufficient for the voters, as they have become increasingly aware of issues related to democracy, participatory, accountability and transparency (Personal communication, October 8, 2019).

\section{Regime Change in Malaysia}

A one-term government would definitely not result in any form of regime change (Personal communication, October 2, 2019). After the regime change, the Pakatan Harapan (PH) government was in a great predicament as it struggled to stay in power until the next general election. The PH government did not deliver many changes throughout the first year in office and was not able to address nation-building, unity, ideological differences, and developmental issues. To everyone's surprise, the government ended abruptly within a year and a half when a new partnership involving the old regime and several PH lawmakers successfully took over power. Regime change is change in an existing stable electoral government as seen in Malaysia. Regime change indicates not just a slow and gradual change as mentioned earlier, but also carries the weight of limited changes, lack of reforms, and the changing perception of the people towards the government (Personal communication, October 8, 2019). Even so, changes that managed to be executed successfully by the regime change may not last. Even after the regime change, the government system has remained intact, particularly in the civil service and bureaucracy sector, and while the government policies and circulars remained the same, people are ought to have an unchanged perception towards the new government as the changes that happened in the state was not a systemic one (Personal communication, October 8, 2019). The government's standard operating procedure had to be followed despite the innate political problems from the previous regime, such as the appointment of high ranking positions based on political affiliation rather than merits, in which such individuals could not be dismissed without going through proper channels unless they voluntarily resigned or their respective contract-term had ended (Personal communication, October 8, 2019).

Regime change made its impact in three essential areas: the diversity of support towards the new government, the restructuring and reforming of major political institutions, and the formulation of new policies that are supposedly more people centric. Firstly, there were changes in the types of support given to the new PH government. Malaysians from different races and regions made up the pillars of the PH government (Loh, 2018). The government commanded a great deal of non-Malays' and non-Muslims' support in various parts of 
Malaysia while the Malays' support came more from urban-based, educated and middle-class communities, due in part to Mahathir's influence in the PH coalition (Loh, 2018). Secondly, several political institutions were being restructured and reformed. A Committee for Institutional Reform was set up, and government agencies such as the Election Commission, Malaysian Anti-Corruption Commission, the Attorney-General's Chambers, Bank Negara and other government-linked entities had their serving heads replaced or were asked to tender their resignations. Other government departments such as the Prime Minister's Department received a much lower financial allocation (Loh, 2018). Thirdly, the people centric policies were being formulated under the PH administration. Some of the new policies include replacing the GST system to lower the cost of living and a Budget 2020 that is more responsive to the people's social welfare and the introduction of a Shared Prosperity Vision 2030 blueprint in creating wealth, justice and fairness for all Malaysians (Loh, 2018).

Perhaps, one of the key features of regime change in Malaysia that had a better lasting impact is the removal of a dominant party system (Personal communication, October 8, 2020; Personal communication, January 14, 2020). Since the regime change in 2018, the UMNO party, despite having the most number of seats compared to its counterparts in the parliament, no longer holds the Prime Minister post or enjoys the kingmaker status in the new coalition of Perikatan Nasional (PN) or Muafakat Nasional (MN), which now includes Parti Pribumi Bersatu Malaysia (PPBM) and Parti Islam Se-Malaysia (PAS). Without the one-party system, the electoral system has become more competitive although carrying out institutional reforms was not part of the electoral package. The prominence of GE-14 brings the undeniable fact that Malaysia had actually undergone regime change even though its effect could be reversed. If the next election sees a competitive two-party system, it would then prove that regime change has been successfully carried out (Personal communication, October 8, 2019).

\section{a. Challenges in the Period of Regime Change}

The removal of a dominant party system in Malaysian politics would generally signifies a regime change. However, the question remains as to whether such a system has been fully removed in a post UMNO-BN era. For the longest time, UMNO has been the leading party in the BN coalition made up of other members such as the Malaysian Chinese Association (MCA), Malaysian Indian Congress (MIC), Malaysian People's Movement Party (GERAKAN), United Sabah Party (PBS), Sarawak United Peoples' Party (SUPP), and so forth. Throughout the BN ruling, UMNO had deeply penetrated the people's constituencies in many states. Many seats held by other BN parties were either heavily assisted or overshadowed by UMNO. For example, $70 \%$ out of the $30 \%$ potential Malay voters in a BN holding constituent in Penang were members or supporters of UMNO (Personal communication, November 18, 2019). Other BN parties would see such credible support as part of the main reason to be in the coalition with UMNO. UMNO's control in the Malaysian political system were unparalleled and unchallenged for over 60 years (Personal communication, November 18, 2019). Its position however was challenged due to the 1 Malaysia Development Berhad (1MDB) scandal. Post GE-14, the opposition coalition spearheaded by UMNO has been resisting changes brought by the $\mathrm{PH}$ government such as organizing massive counter rallies to oppose the ratification of the International Convention on Elimination of Racial Discrimination (ICERD), and regrouping their morale by winning several by-elections (Cameron Highlands, Rantau, Semenyih, Tanjung Piai) in 2019; some with overwhelming majority in the hope that their success could be replicated leading to a winning formula to wrest back the federal government in the next general election (Personal communication, October 2, 2019). Disagreements within the PH coalition members caused a lot of upset and disappointment in the members of the public. The 
public perceived the coalition as unstable compared to the $\mathrm{BN}$ regime where issues of disagreement were less made public (Personal communication, January 14, 2020).

In Post GE-14, BN's dominant system has appeared to change towards a more democratic one, fostering cross party checking and a compromising system, but this has led to an unstable coalition that requires time for the parties to cooperate and reach consensus (Personal communication, January 14, 2020). Passive political and social participation of party members and supporters likely due to strong top down management of political parties further complicate matters. The UMNO party was seen as having an entrenched structure attributed by a sturdy ideological belief, an ability to obtain power, a working patronage system and a strong base support (Personal communication, December 14, 2019). Its representatives, members and supporters were expected to toe the party line or else face certain consequences. Several leaders and grassroots leaders including the former Deputy Prime Minister Tan Sri Muhyiddin Yasin and former Kedah Chief Minister Mukriz Mahathir were sacked from UMNO for questioning the $1 \mathrm{MDB}$ case. Conflicting opinions and policy disagreements were not well tolerated in the Barisan Nasional coalition (Personal communication, January 14, 2020).

The general education system could have also contributed to a lack of social and political mobilization and participation. The changing environment of the education system does little to promote active student interaction and questioning. In local universities, students were required to focus on their studies instead of getting involved in politics and student movements ceased to be politically active (Personal communication, December 14, 2019). The enactment of the 1971 Universities and University Colleges Act prohibited students from joining political protests, campaigns or parties. Prior to the Act, there was some freedom of expression in the higher education system amongst students, which was usually accompanied by protests and demonstrations in the universities (Personal communication, January 14, 2020). The lack of understanding and knowledge about social and political issues further weakened the education system that in turn created a culture where individuals lack the confidence to speak their minds in fear of losing their jobs or promotions. Many of them gained insights and became more politically aware when they were no longer tied to the ideas and affiliations of their previous working environment (Personal communication, December 14, 2019).

\section{b. A Post UMNO-BN Era?}

It is proving increasingly difficult for UMNO-BN to reestablish their once enjoyed dominance in the post GE-14 political system. Unlike the Barisan Nasional coalition where UMNO had dominated, the current UMNO-BN will have to compete with their equivalent partners of PPBM and PAS for similar demographic of voters. This competition is further complicated by the presence of 3 opposition parties, namely Parti Keadilan Rakyat (PKR), Amanah and Pejuang (a newly registered party by the former Prime Minister, Mahathir Mohamad), vying for the same demographic of eligible voters in Peninsular Malaysia in the next general election. The DAP National Political Education Director and former Deputy Defense Minister, Liew Chin Tong, wrote in Twitter that, "No single political party in Malaysian politics will be winning more than 70 parliamentary seats in the next general election" (Liew, 2020), while the PAS Deputy President, Tuan Ibrahim Tuan Man, was quoted to have said, "Whether or not a coalition lasts depends on how we manage it. This is especially when it comes to the issue of dominance, all parties have to be dependent on each other. If someone dominates, it will not last long" (Rahim, 2020).

For the first time in Malaysia's history, a former Prime Minister, Najib Razak, was charged, then "sentenced to 12 years and a nearly RM210 million fine for abuse of power" and "being found guilty of six other charges over accusations of illegally receiving nearly US\$10 
million" in connection with the SRC International Sdn Bhd and 1MDB scandal (Malay Mail, 2020). The sentencing, however, has been put on hold pending an appeal to the appellate court. Almost immediately, UMNO declared its exit from Perikatan Nasional, resulting in a minority government where "no single party or coalition has the majority to form the government" but there were still enough MPs (Member of Parliaments) to support Muhyiddin Yassin as prime minister, albeit on a shakier ground (Zahiid, 2020). Despite UMNO-BN being part of a socalled "backdoor government" (viewed as lacking moral standing), its influence in the current political scene and its relationship with PPBM are becoming less clear. Concerned with divisions among party members, the Minister for Science, Technology and Innovation, Khairy Jamaluddin, has expressed his hope to rebuild UMNO and its rejuvenation (FMT, 2020). In addition, the people are closely watching the current government and some have been quick to criticize their missteps and mistakes (Personal communication, May 31, 2020). With weakening political parties due in part to factionalism, the people's voices and political participation are becoming increasingly important in providing feedback or inputs and serving as another layer of the Check and Balance system.

As the political struggle continues in the midst of the COVID-19 pandemic, the current and future trajectories of Malaysia's politics and democracy can be conceptually explained in Figure 1. When Malaya gained independence and Malaysia was formed subsequently, the colonial masters left behind strong political and democratic institutions. Over time, however, manipulation and domination of political structures in favour of the ruling party affected the functioning and efficacy of democratic institutions. People became disillusioned, triggering electoral rallies that led to certain crucial elections such as the GE-12 (2008), GE-13 (2013) and GE-14 (2018). The continuous pressure imposed on the governing regime would lead to certain reactions from the society and eventually the regime's removal through electoral means. A new government would come into power to replace the old regime and leading efforts to restore democratic values, which would signify a regime change and hence, the conclusion of the first cycle. In the second cycle, hope is placed upon the new regime to fulfill its promises and restore democracy. Failure to do so due to weak governance or political will would lead to disillusionment, leading to the event of electoral rallies and election, and subsequent dismissal of the regime. This could continue for few more rounds until the cycle gradually dissipates. The dissipation will likely depend on a number of factors such as political and social mobilization, strength of the political leader and party, civil society involvement, and the government's stand towards electoral democracy rather than sufficiently mimicking it. It is also important to note that moving from one event to another in the cycle will likely take a few years while the completion of the cycle will take another several years to over a decade (Personal communication, February 7, 2020). When the cycle dissipates, it is anticipated that a political system with stable democracy and governance particularly in the area of election and civil society participation would emerge. Its emergence requires the right ethical education, established infrastructures, well-connected communication, inclusiveness, accountability, patience, commitment and perseverance as well as unity among leaders and the people (Personal communication, February 7, 2020).

In the current situation, Malaysia has undergone the first cycle prior to regime change and is in the process of moving from one event to another in the second cycle, as observed by the outcome of the GE-14 and the formation of the PH government. While in the process of trying to fulfill its election promises and reform political institutions in the country, it encountered obstacles and interference that unexpectedly saw a political crisis where the rightfully elected $\mathrm{PH}$ government lost its power to rule. The opposition were able to partner with PPBM to wrest control under a new leadership. The formation of Muafakat Nasional, a formal coalition of UMNO-BN and PAS, and the possible inclusion of other parties in the future showed that the political dominance enjoyed by a single dominant party of a coalition 
in the past has ended. The Covid-19 pandemic further complicates the situation as people's movements were restricted and attempts to challenge the legitimacy of the new PN government were unsuccessful. There is no clear indication if and when a general election will be held to resolve the crisis and determine the fate of the various political parties in Malaysia.
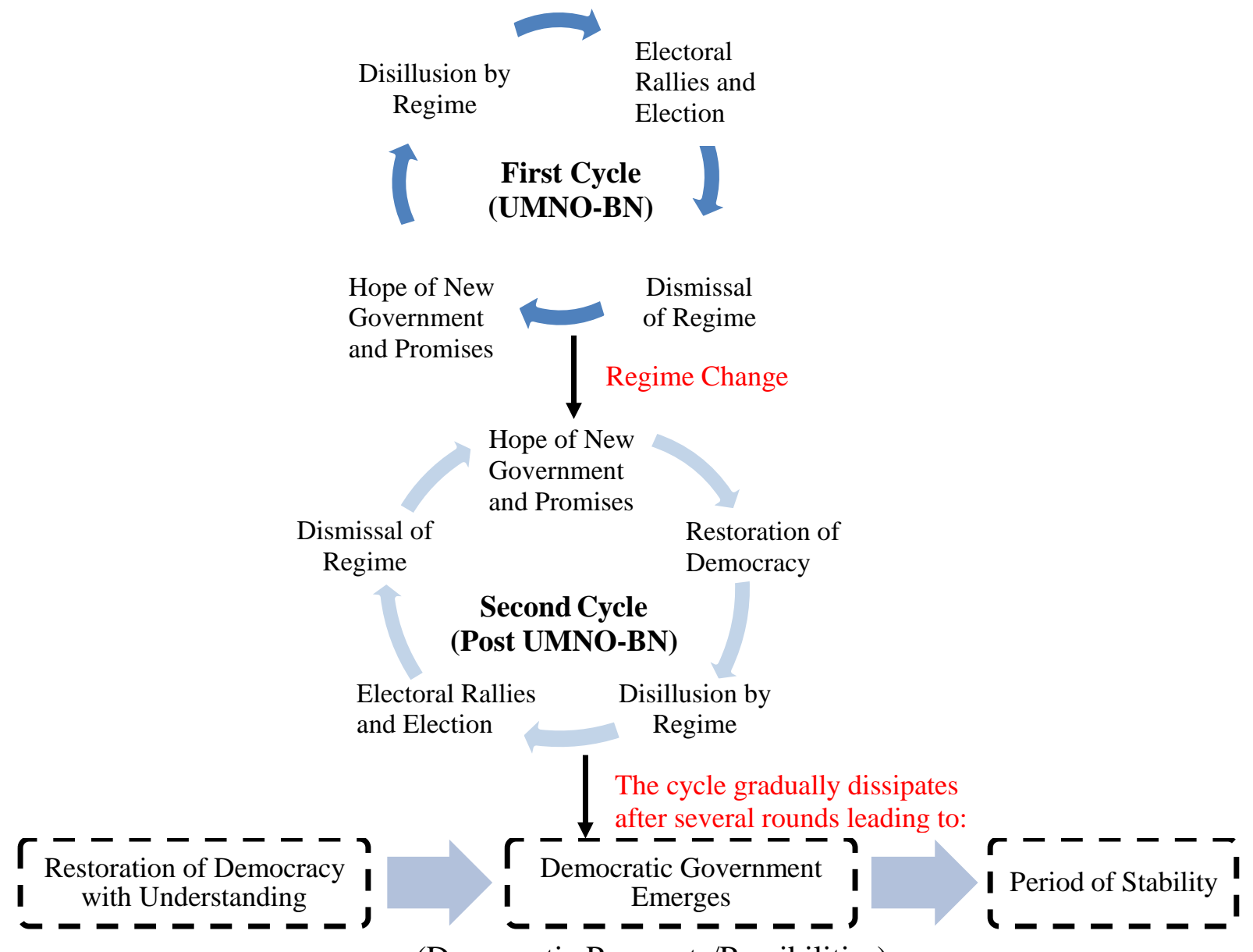

(Democratic Prospects/Possibilities)

Figure 1. A Conceptual Explanation of the Democratic Cycle in Malaysia

\section{Conclusion}

The UMNO-BN regime's involvement in electoral authoritarianism was observed during Mahathir's earlier premiership and briefly ended in Najib's premiership. While there were some observable attributes such as unfair elections, and limitation of civil liberties and human rights, they were subtle in nature and did not severely prevent party supporters from pledging their loyalty to the regime, opposition parties from competing and winning seats in elections, and civil society groups from raising their concerns, or compromise national security and peaceful economic development. The level of sophistication exhibited by the regime has enabled it to sustain political legitimacy, and maintain political authority for over six decades.

Malaysians have sought a change of government through the ballots in GE-14, resulting in a regime change, known to be an uncommon existing electoral government change but not drastic enough to have an overhaul change in the political system. The state of regime change in the post UMNO-BN era in Malaysia has a much more intricate process with many more challenges lying ahead. While the regime change in Malaysia carried a lack of reforms and was unexpectedly short-lived, the power exercised by the electorates in the GE-14 has not only 
substantially weakened the once dominant UMNO-BN coalition but also made an impact in terms of the diverse support given to the $\mathrm{PH}$ government and the realization of new political partnerships as political parties from both sides of the fence manoeuvre the changing political landscape to remain relevant. The challenges that lie ahead of Malaysia's regime change are complicated due to people's differing perceptions and political sentiments, and the abrupt economic downturn brought about by the Covid-19 pandemic.

\section{References}

Case, W. (1993). Semi-democracy in Malaysia: Withstanding the pressures for regime change. Pacific Affairs, 66(2), 183-205.

Case, W. (2011). Electoral authoritarianism and backlash: Hardening Malaysia, oscillating Thailand. International Political Science Review, 32(4), 438-457.

FMT. (2020). Time to rejuvenate UMNO and move on, says KJ. Retrieved from https://www.freemalaysiatoday.com/category/nation/2020/07/28/time-to-rejuvenateumno-and-move-on-says-kj/.

Kinne, B. J., \& Marinov, N. (2012). Electoral authoritarianism and credible signaling in international crises. Journal of Conflict Resolution, 57(3), 359-386.

Liew, C. T. (2020). Liew Chin Tong Status, Twitter. Retrieved from https://twitter.com/ LiewChinTong/status/1287583491073310720.

Lindberg, S. I. (2007). Democratization by Elections in Africa Revisited. American Political Association's 103rd Annual Meeting, (pp. 2-46).

Loh, F. (2009). Malaysia after Mahathir: late democratization amidst development, the strong development state, and developmentalism. In H.-H. M. Hsiao, Democracy or Alternative Political Systems in Asia (pp. 114-136). Routledge.

Loh, F. (2018). Regime change and all that. In A. N. Francis Loh, Regime Change in Malaysia: GE14 and the End of UMNO-BN's 60 Year Rule (pp. 1-6). Selangor, Strategic Information and Research Development Centre.

Malay Mail. (2020). 'We finally feel vindicated': Najib's critics hail guilty verdict. Retrieved from https://www.malaymail.com/news/malaysia/2020/07/29/we-finally-feel vindicated-najibs-critics-hail-guilty-verdict/1889287.

Moniruzzaman, M., \& Farzana, K. F. (2018). Malaysia' 14th general election: End of an epoch, and beginning of a new? Intellectual Discourse, 26(1), 207-228.

Morgenbesser, L. (2020). The rise of sophisticated authoritarianism in Southeast Asia. In E. Aspinall, \& M. L. Weiss, Elements in Politics and Society in Southeast Asia (pp. 1-71). United Kingdom: Cambridge University Press.

Muhamad, N. M. (2018, March). The 14th General Election, the fall of Barisan Nasional, and political development in Malaysia, 1957-2018. Journal of Current Southeast Asian Affairs, 3, 139-171.

Ong, E. (2018). Electoral manipulation, opposition power, and institutional change: Contesting for electoral reform in Singapore, Malaysia, and Cambodia. Electoral Studies, 54, 159171.

Rahim, N. F. A (2020). Tuan Ibrahim: MN will last a long time. Retrieved from https://www. nst.com.my/news/politics/2020/08/618709/tuan-ibrahim-mn-will-last-long-time.

Schedler, A. (2006). The logic of electoral authoritarianism. In A. Schedler, Electoral authoritarianism: The dynamic of unfree competition (pp. 1-23). United States of America: Lynne Rienner Publishers.

Shirah, R. (2016). Electoral authoritarianism and political unrest. International Political Science Review, 37(4), 470-484. 
Slater, D. (2003). Iron cage in an iron fist: Authoritarian institutions and the personalization of power in Malaysia. Comparative Politics, 36(1), 81-101.

Zahiid, S. J. (2020). Lawyers say UMNO snub leaves Muhyiddin's Perikatan Government in a delicate balancing act. Retrieved from https://www.malaymail.com/news/malaysia/ 2020/07/30/lawyers-say-umno-snub-leaves-muhyiddins-perikatan-govt-in-a-delicatebalanc/1889625. 